In the last chapter, which deals with the years since World War I, the story becomes, not surprisingly, more of a local chronicle, albeit within limits useful, detailed, and, as elsewhere, based on thorough research. A success story thread runs through this latter portion, climaxed by the benefactions of Mrs. Bertrand, the donor of a new building (1951) and a $\$ 5,000,000$ library endowment.

This book is a welcome addition to the modest shelf of scholarly histories of American academic libraries.-John C. Abbott, Southern Illinois University, Edwardsville.

\section{Labor Service}

Library Service to Labor. Compiled by Dorothy Kuhn Oko and Bernard F. Downey. New York: Scarecrow Press, 1963. 313p. $\$ 6.50$.

I was pleased to see the publication of this anthology on library service to labor, for much of what has been written appeared originally in publications of limited distribution and has long since gone out of print. Furthermore, many of the librarians and labor educators who pioneered this unique program and recorded their experiences have retired from the scene and a new generation is carrying on the work.

The articles in the collection are taken largely from the Newsletter and Guide of the Joint Committee on Library Service to Labor Groups, established by ALA in 1945, with representatives from libraries and organized labor. They are written by thirtyfour librarians and labor educators, including such veterans as Dorothy Bendix, who for a number of years directed the service to labor at Newark Public library; Ida Goshkin of the Akron Public library; Ruth Shapiro, formerly with the Milwaukee Public library; and-from the labor movement-John Cosgrove and Otto Pragan of the AFL-CIO Department of Education, J. W. O'Connell of the International Association of Machinists, and Sally Parker of the American Federation of Teachers. University programs in workers' education and labor relations are represented by Anthony Luchek of Wisconsin, Shirley F. Harper of Chicago, and others. I miss Mark Starr of the Ladies' Garment Workers in the anthology, but perhaps what he has written is more readily available elsewhere.
The selection was made and appropriate commentary provided throughout by Mrs. Dorothy Kuhn Oko, long-time head of labor service at the New York Public library and for many years the guiding force on the joint committee, and by Bernard F. Downey, librarian of the Institute of Management and Labor Relations at Rutgers.

The anthology opens with several articles explaining why labor has been singled out for special library attention and presenting the historical background of cooperation between librarians and trade unionists. There follows a number of articles on the practical aspects of establishing and operating public library programs directed to organized labor, building labor book collections, and serving educational programs conducted by trade unions. Finally, there are reprints of case studies of public libraries that have had exemplary programs for labor: Akron, Boston, Milwaukee, New York, and Newark. A related area, not covered by the collection, is the interpretation of the labor movement and labor problems to students, a concern of many high school librarians. But perhaps this is another book.

There is a good balance between the practical "how to do it" and the inspirational "why it's worth doing." Perhaps more than any other area of librarianship, service to labor calls for personal involvement in and sympathy with the group to be served. It is not the kind of library assignment that one can accept casually, and, for many, it has become a lifelong career of dedication. Much of this spirit is reflected in the pages of this anthology, which should serve as a handbook and guide to the present generation of librarians serving labor groups.-Ralph E. McCoy, Southern Illinois University.

\section{Lilliput}

The Small College Library. By Sister Helen Sheehan. Westminster, Md.: The Newman Press, 1963. 216p. \$3.50.

The happy conjunction of a thorough and level-headed approach to a great need, and adequate and proper backing by the ACRL has resulted in this small volume the intent of which is to 'translate theory into action.' The theory concerns several aspects of management of the small academic library, and 
the action sought is the practice of the best present library methods which are applicable to a small collection and a small staff. The book is slanted toward that neglected area of our profession which involves 'one-man' libraries, of which there are many, and to college libraries with a staff of as many as three, of which there are many more. The author even assumes, and rightly, that many of these librarians may be without benefit of professional training.

The text is clear, thorough in treatment of the areas chosen, but concise in statement and precise in reference not only to accepted library practices but also to the most essential tools and professional literature and organizations. The latter is an indication of the author's very gentle but firm persuasion of those library staffs which are least likely to do so to participate in and benefit from such organizations, notably the ALA.

The value of this book lies in its orientation and emphases. Nothing really new in library method or administration has been said. What has been said has been said well, and with the exception of some slight confusion arising from a lack of sufficient subheads, the book is very readable. Strong points include its emphasis on budget matters, an avowedly knotty problem for any library administrator; its numerous but pertinent appendices; and an adequate index.

This volume is deceptive in its simplicity. It is a mine whose wealth may be acquired easily by both professional and nonprofessional staff members of the small college library, and it should soon find its way as well to the reading lists of library science courses in college library administration.John David Batsel, Lambuth College.

\section{Books Briefly Noted}

Annotated Guide to Reference Materials in the Human Sciences. By A. K. Mukherjee. New York: Asia Publishing House, 1962. 267p. \$8.50.

Bibliographica Neerlandica. Compiled by A. M. P. Mollema and P. M. Morel. The Hague: Nijhoff, 1962. 598p. f 48.-

Biblioteka; Wprowadzenie do zagadnien budowy. (An Introduction to Library Building Problems.) By Wladyslaw Piasecki. Warsaw: Stowarzyszenie Bibliotekarzy Polskich, 1962. 120p.

Copyright Law Revision, Part 2; Discussion and Comments on Report of the Register of Copyrights on the General Revision of the United States Copyright Law. House Committee on the Judiciary. Washington, D.C.: Government Printing Office, 1963. 419p. \$1.25.

Directory of Business and Financial Services; a Project of the Business and Financial Division. Edited by Mary A. McNierney. New York: Special Libraries Association, 1963. 6th ed. 187p. $\$ 6.50$.

Foreign Newspapers in Southeastern Libraries; Sponsored by the Association of Southeastern Research Libraries. Edited by William Stanley Hoole. University, Ala.: University of Alabama Press, 1963. 64p.
German-English Chemical Terminology; an Introduction to Chemistry in English and German. By Alexander King and Hans Fromherz. Weinheim: Verlag Chemie, 1963. 4th ed. revised and enlarged. 588p.

Guide to Russian Reference Books. By Karol Maichel. (Hoover Institution Bibliographical Series, no. 10). Stanford University, Calif.: The Hoover Institution on War, Revolution, and Peace, 1962. 92p. $\$ 5.00$.

History of Early Ukranian Printing, 14911600. By Lubomyr R. Wynar. (Studies in Librarianship, v.1, no. 2). Denver: University of Denver Graduate School of Librarianship, 1962. 96p. $\$ 2.50$.

Informe; Reunion Tecnica de Bibliotecas Agricolas de Colombia, 30 de Julio-17 de Agosto de 1962. Auspiciada por la Escuela Interamericana de Bibliotecologia con la colaboracion de la Facultad de Agronomica e Instituto Forestal Universidad Nacional de Columbia. Medellin, Colombia: Escuela Interamericana de Bibliotecologia, 1962. 229p.

The Library of Tomorrow-Today; an Information Service of Educational Research Materials. Edited by Pamela W. Reeves, et al. Cleveland: Center for Documentation and Communication Research, 1962. $326 \mathrm{p}$. 